\title{
USING SHORT FILMS FOR TEACHING ENGLISH WHILE BUILDING CHARACTERS
}

\author{
Jesica Vanessa Hutapea ${ }^{1}$, Ni Komang Arie Suwastini ${ }^{2}$ \\ 1,2 Universitas Pendidikan Ganesha \\ e-mail: jesicahutapea17@gmal.com , arie.suwastini@undiksha.ac.id
}

\begin{abstract}
The role of teachers in EFL/ESL classroom is very important for the improvement of the students since it is believed that professional and creative English teachers can help students in learning English well. However, many teachers still lack the effort in finding new ideas and in improving their professionalism as a good English teacher. Yet, with the development of technology nowadays, many media are worth to be considered in teaching English. One of the media that is being actively mentioned in educational world nowadays is short film. In this case, short film is believed to be one of the appropriate ways in teaching English especially in teaching the character education presented in it. With short film, students can have more exposure to authentic English and the culture of the target language. But another important benefit is often overlooked by teachers, that is the possibility of learning values for building the students' characters through the use of short film in the learning process. This present paper will try to respond to this fact by identifying the values of character educations in a short film entitled Piper from Pixar animation through textual analysis. There are character educations that revealed about parenting, self-supporting, and friendship value in the film. Thus, it can be concluded that when chosen correctly, short films can be a media for building students' characters while developing their English, all in a more entertaining, relaxed, and enjoyable media that meet the students' $21^{\text {st }}$ century contexts.
\end{abstract}

Keywords : EFL/ESL, short film, character education, textual analysis

\section{INTRODUCTION}

In the era of $21^{\text {st }}$ century, the world needs human beings who are not only intelligent in cognitive abilities, but also those with moral quality. Moreover, Indonesia's 2013 curriculum emphasizes on character education in order to build better personality. Good manner cannot be shaped without character education. In addition, education loses its worth without character building. Therefore, character education understanding is very important to be deepened. Character is a habit that is created from individual's behaviors and character education is about teaching moral values (Kohn, 1997 in Stedje, 2010). Character education is very important for students because character education persuades students to treat other people in a good way, increasing critical thinking ability and increasing individual's moral value, and also developing good personality and emotional skill in order to have good communication in collaborative working (Victor, 2000 in Stedje, 2010).

Character education can be found in short films that are functioned as learning media. Short film is one of the learning media that is worth to be used in teaching learning process. Sudiran (2015) states that varied learning media is very important in helping teaching process and also in increasing interesting learning atmosphere so that students can understand the subject well. Short film is an effective learning media since it enhances students' ability in thinking creatively and students' developments in increasing English competencies (Kadabadayi, 2012). Short film that has 6-40 minutes (or less) of duration eases the teacher in teaching the students; since it is short, short film can be repeated and students become more focused to a certain 
subject in the film (Kadabayi, 2012). Moreover, a short film has to be short in order to deliver the meaning by giving a simple (not too complicated) idea or basic idea to the spectators (Cooper and Dancyger, 2005). This means that short film can make students think critically and it can enhance students' ability of memorization. Short film existence also takes role in enhancing students' English competencies (writing, reading, listening, and speaking); students not only watch and listen everything from the film, but it can trigger the students to have discussion and share their opinions toward the film.

Piper is a computer-animated short film that is produced by Pixar Animation Studios in 2016. It is a story about a peep (the child) that wanted to look for some food at the beach, but the peep was tend to be scared of the wave. The sandpiper (the mother) and the hermit crab helped him in the learning process of looking for shells. The story of the short film tells many values that can be taken and there are many character educations that can be found in Piper. Furthermore, the character educations can be seen focus from the setting, costume, lighting, and acting (mise-en-scène). Mise-en-scène is all preparations that are going to be put in the scene in order to affect the audience's emotional, so that it can influence the audience in experiencing of watching film (Bordwell and Thompson, 2008). Mise-en-scéne can give deeper understanding about the characters of the film to the audience. Since Piper is a silent animated short film, the film can build students to think creatively and critically. Silent short film can make the students to use more their imagination and understanding since silent short film uses visual imagery in delivering the message, therefore it can train students to learn independently and use their sense in building the stories and analyzing the characters (Kartika, Susilo, Natsir, 2017). The analysis aims to reveal the character educations that can be found in the short film, Piper.

\section{METHOD}

The research design, setting, data collection and analysis are encircled the method of this research. This will explain the structure of this research in analyzing the character education of Piper animated short film.

This research used qualitative research design. Qualitative research is an observation method in order to gather data that is not a numeric data (Babbie, 2014). This research analyzed about short film which was focused on the analyzing the character education that was presented in the film scenes.

This research occurred from a computer-animated short film by Pixar Animation Studios or commonly known as Pixar. Pixar Animation Studios is an animation film company that has produced many animated films and short films, and many of their film productions have spread worldwide. Most of Pixar's films use the CGI technology which makes the animation looks more alive and attract the audience, especially children. Moreover, short film productions from Pixar are able to be watched by all ages. The reason of choosing film by Pixar Animation Studios was because most of children and teenagers already recognize animated films from Pixar and most of their films are dedicated for children's or teenagers' consumption. In addition, the content of Pixar's short films can be understood and worth to be consumed by children or teenagers since the content itself is less negative and less pornographic.

In this analysis, the technique of data collection and method of data analysis were used. First, the technique of collecting the data was conducted by watching the short film for several times and then followed by making notes and dividing the scenes from the film into parts. Second, textual analysis was used to analyze and gain the data. Textual analysis is a theoretical general approach that focusing on the texts or on discourse analysis that is relevant to each other (Beaugrande, 1985 in Garzone, 2000). Moreover, it is a research method that gathering the data by interpreting texts and reality (society, cultures, trends, etc.) (McKee, 2003). Textual analysis has purpose that is to explain the description of content, structure, messages (Frey, Botan, \& Kreps, 1999). This means that the textual analysis method can be used to get meaning from a 
passage, motion picture, or even an art work (McKee, 2003).

\section{FINDINGS AND DISCUSSION}

A short film uses limited characters in the story, but with the limitation of the duration and the characters, the message of the film has to be delivered to all spectators. The short film existence gives opportunities for both teacher and students, because short film can be used as the learning media and a guide for students to build their own character. Piper is an animated short film that is produced by Pixar Animation Studios in 2016 and it is directed by Alan Barillaro. Piper has the duration of 6 minutes; there is one main character, that is the peep, and the supporting characters are the mother (the sandpiper) and also the peep's friend (the hermit crab).

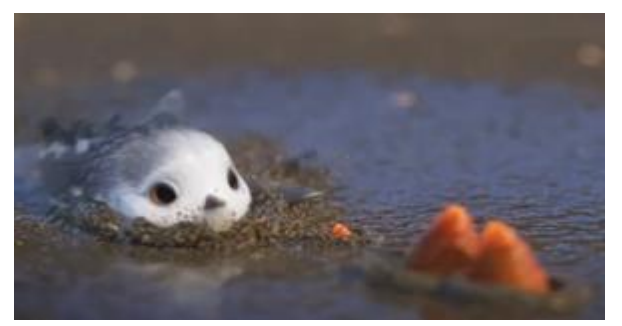

Figure 1. The peep also hoarding itself into the sand

\section{Parenting Education}

Children need to be guided in their life. Children need parents to guide and educate them. Therefore, to be a parent, it is necessary to learn about parenting, so later on a parent knows how to face child's emotion and changes. By learning about parenting education, a mother or a father can understand more about child's attitude, needs, feelings, and the respectfulness between parents and children (Polivanova, Vopilova, \& Nisskaya, 2016). In the Piper, the way of the mother (the sandpiper) educated its own child was shown in several scenes.

In the beginning of the film, the sandpiper wanted its child to be more active and not be spoiled (00:54). The sandpiper used its beak and gave a little tickle to the sleeping peep. The mother also tried to wake up its baby from the sleep. The sandpiper's action towards the peep intended to persuade the peep to be more active and not be lazy. In other words, the sandpiper wanted its baby to do some activities; the mother tried to make the peep to go out and see everything outside instead of staying in the nest.

Moreover, Piper also wants to deliver a value about educating children to be an independent. The sandpiper walked to the seashore and showed a shell towards the peep, she invited the peep to join looking for some food (01:13). By inviting the peep to join the sandpiper, the sandpiper wanted the peep to learn looking for food. However, the peep showed a response $(01: 17)$ to its mother (the sandpiper) by opening its beak. It means that the peep wanted to be fed by its mother. In here, the peep wanted to be spoiled by its mother. However, the mother showed an opened shell to the peep (01:25) and the mother still tried to persuade the peep to come to the seashore. When the peep found its mother, the mother was grabbing a shell from the sand using its beak and the peep opened its beak again for the second time (01:46). In other words, the peep wanted its request be fulfilled or it can be said that the peep was little bit lazy. But the mother pushed the peep gently using its beak (01:48). The action of the mother implies that the mother taught the peep to be independent.

\section{Problem solving}

When we try to do a new activity, usually we do an observation and pay attention to some steps. When we pay attention to the 
steps, we actually follow the actions from the step and imitation happens when we try to follow someone's action. Imitating is a part of education because in the process of learning something usually people tend to imitate someone, like parents, teacher or even a stranger. Warnick (2008) states that imitation is an activity of repetition that the people's attitude or their activities are being the reason way people imitation someone shows the social learning and shows the same interest in order to build a communication (Dutenhahn \& Nehaniv, 2002). When a person imitates someone, then the person is not only following but the person is observing, learning something new and getting new information (Warnick, 2008).

In the film, the peep finally wanted to look for some food but he's still afraid of the water that would drench the peep. The peep started to observe the situation when it saw the family of hermit crabs dug the sand out and hid under the sand dump (03:32). From the way the peep was standing and kept looking at the hermit crabs, it could be shown that the peep was observing hermit crabs. This means that that the peep was trying to follow the steps of what the hermit crabs were doing. But then when the wave was coming, the peep was afraid and after the peep that ran towards the hermit.

\section{Friendship}

Friendship can be started everywhere, it probably starts when two women are having a small conversation because they're looking for the same clothes in a store or it can be started when a stranger helps a woman to bring a heavy box upstairs. In the process of friendship, someone has to introduce herself or himself by shaking hands or only talking and then the conversation would start in order to know each other.

Piper also tells about friendship value in the scenes. In the scene, the peep was panic and it's running toward the hermit crabs that were just drenched by the incoming wave (03:37). It means that the peep wanted to give a help if there something happens with the hermit crab. In other words, the peep cared about its new friend.
In this scene the peep came closer to the hermit crab and watched it moving (03:41). The peep's body was a bit bowing down and it continued watching the smallest hermit crab and it only wanted to watch the smallest hermit crab. So, it means that the peep only wanted to learn from the smallest hermit crab.

When the peep was busy to watch the hermit crab, all of a sudden, the wave was coming toward them and the peep was really afraid of the wave. So then, the peep followed as the hermit crab did (04:01). The action of the peep means that the peep wanted to be safe from the wave by following the hermit crab (Figure 1) and it also connotes that the peep was doing the imitation. Without realizing it, the peep has learned to solve the problem by doing imitation. In another scene, when the peep and the hermit crab were submerged in the water, both of them actually could see all the shells under the water, so later when the water receded the peep could locate the shells. After that the peep brought out the shells to the mother, the hermit crabs and also other birds. And then the peep was going to look for some food again. In minute 05:06 the peep wanted to be close to the sea and hoard itself into the sand. It means that the peep was doing the same thing again as the peep has learned from the hermit crab previously.

In another scene, when the peep and the hermit crab were submerged in the water, the hermit crab pats the peep's beak (04:11) and in response, the peep opened its eyes and they saw the shells under the water. The hermit crab wanted to show something to the peep. It means that the hermit crab wanted its friend to see the same thing and the hermit crab wanted to share little happiness to the peep.

When the peep was already able to locate the shells, the peep took out some shells to be eaten by its mother and the hermit crab and its family (04:58). The action of taking out the shells from the sand implies that the peep wanted to share the shells to its mother and the hermit crab family. So, the peep was not selfish and gave everyone the food including its new friend, the hermit crab.

In minute 04:34, both the peep and the hermit crab were happy because they have 
seen a lot of shells under the water. The peep approached its beak toward the hermit crab, they're doing little celebration (the high five gesture). The peep was sharing happiness with the hermit crab and the peep appreciated the help from the peep's new friend, the hermit crab.

\section{CONCLUSION}

While short film is able to ease teacher in teaching English, short film also gives opportunity for the students to be more critical. This study explains the advantages of using short film since moral or character education needs to be learned by the students. Piper short film teaches the audience about education that takes from parents' and children's point of view, and also the friendship value. It is believed that Piper is one of the media for teaching that not only helps teachers to teach character education, but also as an interesting media to teach English in the class.

\section{REFERENCES}

Babbie, E.R. (2014). The Basics of Social Research $-6^{\text {th }}$ ed. California: Wadsworth, Cengage Learning.

Battistich, V. (2000). Character Education, Prevention, and Positive Youth Development, University of Missouri, St. Louis. Character Education Partnership. In Stedje, L.B. (2010). Character Education - A Literature Review. Oklahoma: Character First.

Beaugrande de, R. (1985): "Text Linguistics in Discourse Analysis", in Handbook of Discourse Analysis, vol. 1: Disciplines of Discourse. Ed. by T.A. van Dijk, London, Academic Press, pp.41-70.

In Garzone, G. (2000). Textual analysis and interpreting research.

The Interpreters'Newsletter. (10), 6988.

http://hdl.handle.net/10077/2449

Bordwell, D. \& Thompson, K. (2008). Film Art: An Introduction $-8^{\text {th }}$ ed. New York: McGraw- Hill.

Cooper, P. \& Dancyger, K. (2005). Writing the Short Film Third Edition. London, UK: Elsevier Focal Press.
Dautenhahn, K., \& Nehaniv, C. L. (2002). Imitation in animals and artifacts. Cambridge, MA: MIT Press, pp. 1-40.

Frey, L. R., Botan, C. H., \& Kreps, G. L. (1999). Investigating Communication: An Introduction to Research Method. Boston: Allyn \& Bacon.

Kadabayi, L. (2012). The Role of Short Film in Education. Procedia - Social and Behavioral Sciences. 47, 316-320.

Kartika, R.A.R., Susilo, S., \& Natsir, M. (2017). The Effect of Silent Short Movie on EFL Writing Achievement of Vocational High School Students. Jurnal Pendidikan Vokasi. 7(2), 168-179.

Kohn, A. (1997). How Not to Teach Values: A Critical Look at Character Education. Phi Delta Kappan. 78(6), 428-439. In Stedje, L.B. (2010). Character Education - A Literature Review. Oklahoma: Character First.

McKee, A. (2003). Textual Analysis: A beginner's guide. California: SAGE Publications.

Polivanova, K., Vopilova, I., \& Nisskaya, A. (2016). Parenting education history and modern trends:

Self-efficacy methodological base for the development of educational programs for parents. Framework of basic research program at National Research University Higher School of Economics, Institute of Education. 4,4-19.

https://publications.hse.ru/en/preprint s/179265519

Sondheimer, M. (Producer) \& Barillaro, A. (Director). (2016). Piper [Motion Picture]. United States: Pixar Animation Studios.

Sudiran. (2015). Students' Perception Towards the Use of Internet as Learning Media to Promote Reading Comprehension Skill. Sino - US English Teaching. 12(9), 684-692.

Warnick, B.R. (2008). Imitation and Education: A Philosophical Inquiry into Learning by Example. Albany, New York: State University of New York Press. 